\title{
CYTOSTATIC EFFECT OF CYCLOPHOSPHAMIDE ON BONE MARROW IN SHEEP
}

\author{
B. HOFÍREK, J. DRÁBEK
}

\begin{abstract}
Department of Diagnostics, Therapy and Prophylaxis, Department of Pig Diseases, Animal Breeding and Animal Hygiene, University of Veterinary Science, 61242 Brno
\end{abstract}

Dedicated to the 50th birthday of Prof. MVDr. P. Jagoš CSc.

Received February 2, 1980

\begin{abstract}
Hofírek B., J. Drábek: Cytostatic Effect of Cyclophosphamide on Bone Marrow in Sheep. Acta vet. Brno 49, 1980: 217-222.

Cyclophosphamide $\left(25 \mathrm{mg} . \mathrm{kg}^{-1}\right)$ at a concentration of $2 \%$ was administered intravenously to Merino sheep. A cytologic picture of bone marrow prior to and 22 days post administration was followed.

Following the administration of the cytostatics a short-term and temporary depression in hemopoiesis was observed, the red component of bone marrow being more affected. In the white component only more mature cells (neutrophil metamyelocytes and stab granulocytes) were decreased in number. In both bone marrow components the short-term depression lasting 2-4 days was followed by an increase both in erythro- and myelopoiesis, persisting throughout anemia or leukopenia in peripheral blood. It was found that the administration of cyclophosphamide at this dose does not induce permanent effects in bone marrow which preserves its full regeneration ability. This conclusion is also confi med by the modification of peripheral blood picture and by the course of experiment when no disturbance in clinical condition of sheep appeared.
\end{abstract}

Sheep, cytostatics, cyclophosphamide, blood, bone marrow.

Considering the development of sheep breeding and the increase of their stock, the intensive technology of their rearing, facilitating high productivity, is important for Czechoslovakia. One of the problems to be solved is the replacement of tiresome labour connected with mechanical wool shearing. Moreover, the problem is aggravated by a persisting lack of skilled clippers. Possibilities are, therefore, sought in the rationalization of this labourious task, particularly by using the chemicals with cytostatic effects affecting also the hair follicles.

Cytostatics are known to influence all cells of a living organism and it is, therefore, necessary to examine possible negative effects upon the sheep health condition. One of the chemicals considered is cyclophosphamide.

Dolnick et al. (1969) was one of the first who studied the possibility of chemical release of fleece; he proved that the dose of $30 \mathrm{mg} . \mathrm{kg}^{-1}$ was not toxic for sheep. When studying the side effects of cyclophosphamide the changes of some hematologic or biochemical values of blood were followed. Ziegler et al. (1972) demonstrated that after intraruminal administration of $30 \mathrm{mg} \mathrm{kg} \mathbf{~}^{-1}$ significant leukopenia occurred at 8th day, reaching half the normal value, and lasting till the 27th day. Almost no effect was observed on erythrocytes and hemoglobin. Skalka et al. (1972) applying a dose of $20 \mathrm{mg} \cdot \mathrm{kg}^{-1}$ removed the fleece during 14th $-21 \mathrm{st}$ day following the cyclophosphamide administration. They also examined its effect upon the blood picture of experimental sheep. The decrease of leukocyte count was found to be most striking whereas the hemoglobin and hematocrit values decreased only on the 3rd-5th day, other hematologic and biochemical values (transaminases GOT, GPT, total protein, bilirubin, glucose, $\mathrm{P}, \mathrm{Mg}, \mathrm{Cu}$ and $\mathrm{Fe}$ ) not showing significant changes 
in mean values. In our previous work (Drábek, Hofirek 1977), concerned with the same problem, we found that following a dose of $25 \mathrm{mg} . \mathrm{kg}^{-1}$ of cyclophosphamide a significant decrease of erythrocyte count, hemoglobin and hematocrit had occurred. The induced anemia was of macrocytic and normochromatic character and in no case reached the clinical stage. Extensive leukopenia and changes in the white cell count also appeared.

In our previous paper (Drábek, Hofírek 1977) as well as in this work the results of cytostatic effect of cyclophosphamide on bone marrow of experimental sheep have been presented. There are no available literature data concerning this topic although this problem has been studied in man. Fernbach (1967) reported that elevated and repeated doses of cyclophosphamide in man inhibited the bone marrow function, resulting consequently in neutropenia, thrombocytopenia and anemia.

\section{Materials and Methods}

Cyclophosphamide ( $2 \%$ solution) was intravenously administered in a single dose of $25 \mathrm{mg}$. . $\mathrm{kg}^{-1}$ to eight clinicaly healthy l-year-old Merino sheep. The experiment was carried out in November and December. During 24 days of experiment the samples of bone marrow and peripheral blood were collected six times, i.e. $1 \times$ prior to and $5 \times$ after the cytostatics application (day $2,4,8$, 10 and 22 of experiment).

The bone marrow was taken by sternal punction using the aspiration method. From the obtained samples the marrow smear was prepared on glass slides and stained according to May-Grünwald-Giemsa. From the smear of each sheep at least 500 cells of leukocytic maturation series (expressed in \%) and corresponding number of erythrocytic maturation series were evaluated. From the results obtained the maturity index and the myeloid: erythroid ratio were calculated.

From the peripheral blood the erythrocyte (RBC) and leukocyte (WBC) counts were determined on a Coulter-Counter Model $\mathrm{D}_{\mathrm{N}}$ automatic counter.

Results are summarized in Table 1 and Fig. 1 and 2.

\section{Results and Discussion}

Our results have shown a short-term but marked cytostatic effect of cyclophosphamide on bone marrow.

In the erythrocyte maturation series of bone marrow (Table 1 and Fig. 1) follow-

Table 1

Dynamics of changes in sheep bone marrow following i. v. administration of $25 \mathrm{mg}^{. \mathrm{kg}^{-1}}$ cyclophosphamide

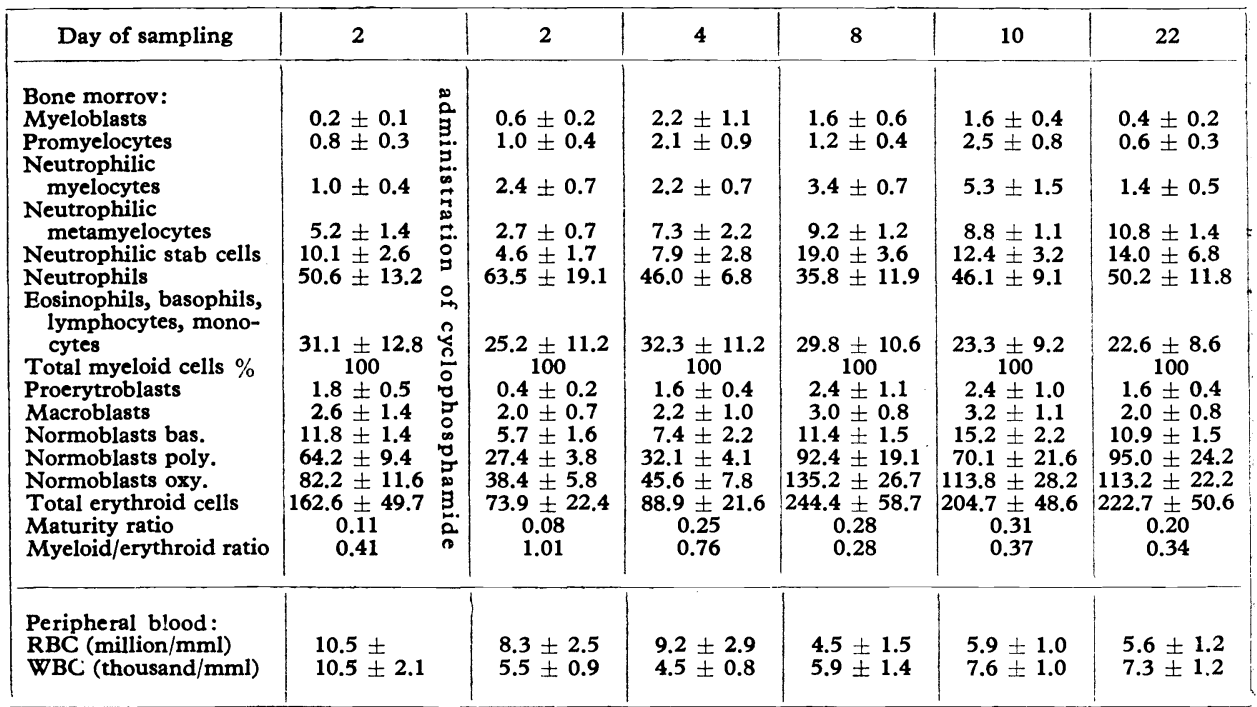


ing changes were observed: already on the 2nd day following the cytostatics administration the decrease of proerythroblasts was observed but from the 4th day a gradual increase, reaching its peak between day 8 and 10, was recorded. At the end of experiment on the 22nd day the count of these cells was equivalent to that before the cytostatics application. Similar tendency could be observed in macroblasts. All forms of normoblasts reacted to administered cyclophosphamid in the same way although in this case the depressive effect of cytostatics was more pronounced, particularly in oxyphilic and polychromatophilic normoblasts. Generally, the changes in erythrocyte maturation series of bone marrow can be characterized by an erythropoietic depression till the 4th day after the cytostatics administration followed by a hyperfunction induced by persistent anemia in peripheral blood lasting practically till the end of experiment. This observation is supported also by a total number of cells of erythrocytic maturation series where the original value of $162.6 \pm 49.7$ prior to cytostatics application decreased on the 2nd and 4th day to only $73.9 \pm 22.4$ and $88.9 \pm 21.6$, resp. From the 8th day persistent hyperplasia of bone marrow, the cell count being over 200 , and lasting till the end of experiment, has been observed.

In leukocytic maturation series of neutrophil granulocytes(Table 1 and Fig. 2) following changes have also appeared: shortly after cyclophosphamide administration the mature neutrophilic granulocytes found in bone marrow increased which was followed immediately by their decrease,

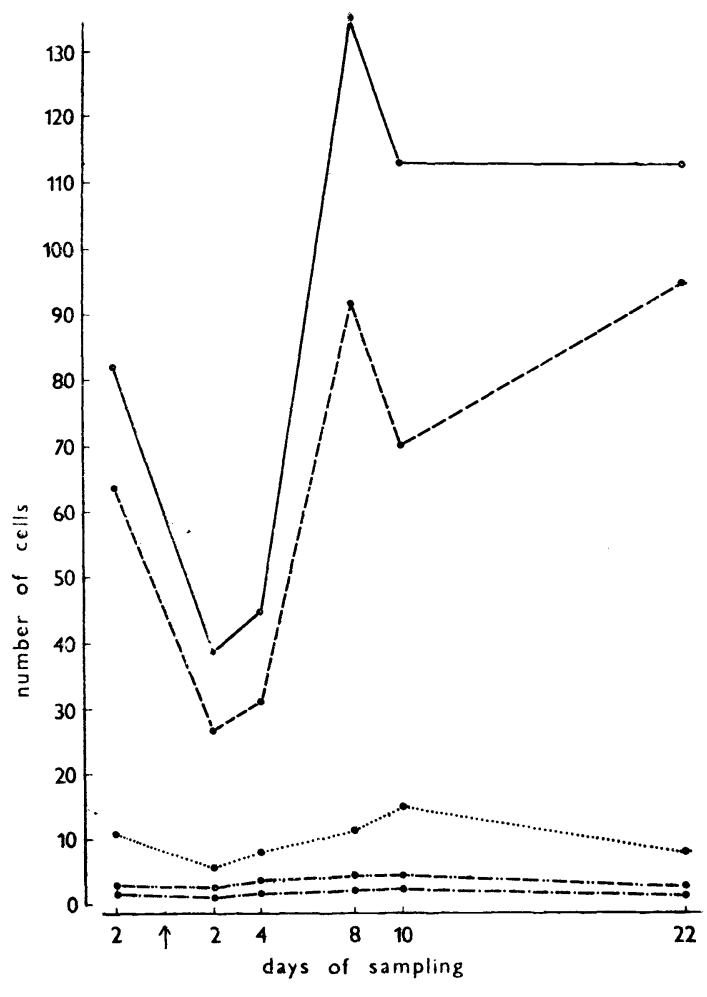

Figure 1:

Changes in number of bone marrow erythroid cells in sheep following i. v. administration of $25 \mathrm{mg} \mathrm{kg}^{-1}$ of cyclophosphamide

normoblasts oxyphilic; - - - - normoblasts polychromatophilic; .... normoblasts basic;

- -... - . macroblasts; -...-. proerythroblasts reaching a minimum on the 8 th day. At this time also leukopenia was culminating in peripheral blood. Later an increase of these cells in bone marrow appeared so that at the end of our experiment their count returned to the original value prior to cytostatics application. A somewhat different reaction was observed in stab neutrophil granulocytes and neutrophil metamyelocytes. The myelopoiesis depression of these cells reached the minimum already on the 2nd day after the cyclophosphamide application but was immediately followed by its increase; otherwise the tendency was the same as in the case 


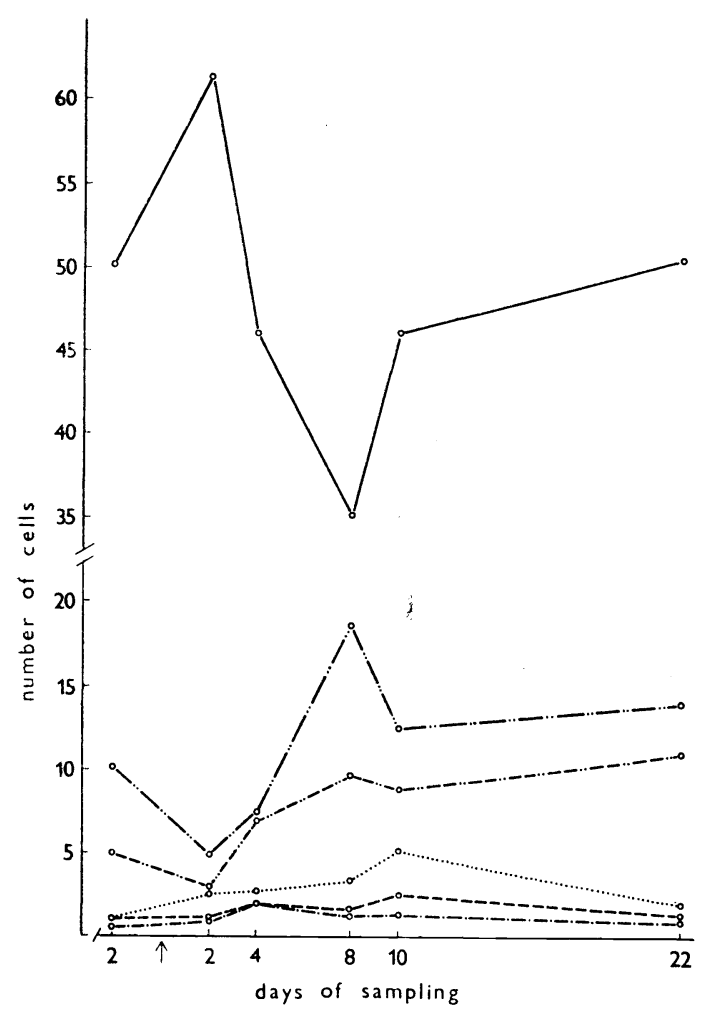

Figure 1:

Changes in number of bone marrow myeloid cells in sheep following i. v. administration of $25 \mathrm{mg} \mathrm{kg}^{-1}$ of cyclophosphamide

neutrophils; ..__... stab neutrophils;

..--..--metamyelocytes neutrophilic; .... myelocytes neutrophilic; - - . - promyelocytes; ...-.--myeloblasts of neutrophil granulocytes. This provocation of myelopoiesis is probably the result of persisting leukopenia in peripheral blood. The depressive effect of cyclophosphamide on the formation of myeloblasts, promyelocytes and neutrophil myelocytes was not observed but their later myelopoiesis is well evident, being most pronounced in the case of neutrophil myelocytes which reach their culmination on the 10th day following the cytostatics administration. The reaction of promyelocytes and myeloblasts was essentially the same. At the end of our experiment (day 22) the number of all these cells was returning to the original values found prior to cyclophosphamide administration.

When evaluating changes in white component of bone marrow in comparison with changes in the red one a certain difference could be observed. All cells of the red component of bone marrow reacted identically, which was not the case of white component, particularly immediately after the cyclophosphamide administration. Quite a short-term increase in the count of mature neutrophilic granulocytes can be explained as a response to cyclophosphamide administration which, before exhibiting its cytostatic effect, acted shortly as an antigen, this being the reason why the depression has probably been observed in most immature cells of white myeloid series of bone marrow.

When evaluating the overall effect of cyclophosphamide on bone marrow we believe that the influence of these cytostatics on the red component is more marked than on the white one. The results of our experiment have, however, shown that the depressive effect of these cytostatics on hemopoiesis is only a temporary one with short duration and that both erythropoiesis and myelopoiesis are not permanently suppressed. On the contrary, both components preserved their ability of rapid regeneration which was manifested by increased erythropoiesis and myelopoiesis throughout anemia and leukopenia in peripheral blood. It can therefore, be generally said that the intravenous administration of $25 \mathrm{mg} \cdot \mathrm{kg}^{-1}$ of cyclophosphamide to sheep does not result in permanent damage of bone marrow which 
preserves its ability of full regeneration. This conclusion is further confirmed by the modification of peripheral blood picture and by the course of experiment when no disturbances of clinical condition of sheep appeared. Thus we essentially confirmed the results of other authors, even though different parameters were followed, reporting that the administration of a reasonable dose of cyclophosphamide for the purpose of chemical fleece removal is not toxic (Dolnick et al. 1969; Ziegler et al. 1972; Skalka et al. 1972; Drábek, Hofírek 1977).

\section{Cytostatický účinek cyklofosfamidu na kostní dřeň ovcí}

Ovcím plemene žírné merino byl aplikován i. v. cyklofosfamid $\mathrm{v}$ dávce $25 \mathrm{mg} / \mathrm{kg}^{-1}$ ve $2 \%$ koncentraci. Byl sledován cytologický obraz kostní dřeně př̃ aplikací a 22 dnů po aplikaci.

Po podání cytostatika byla zaznamenána krátkodobá a přechodná deprese hemopoesy, přičemž byla postižena více červená složka kostní dřeně. U bílé složky došlo $\mathrm{k}$ depresi jen u zralejších buněk (neutrofilní metamyelocyty a tyčkovité granulocyty). U obou složek kostní dřeně po krátkodobé depresi trvající $2-4$ dny došlo ke zvýšení jak erytropoesy tak myelopoesy, které trvaly po celou dobu anémie nebo leukopénie $\mathrm{v}$ periferní krvi. Bylo zjištěno, že podávání cyklofosfamidu v uvedené dávce nevyvolává trvalé následky v kostní dřeni, která si uchovává schopnost plné regenerace. Tento závěr potvrzuje také úprava periferního krevního obrazu a celý průběh experimentu, kdy nedošlo $\mathrm{k}$ narušení klinického stavu ovcí.

\section{Цитостатическсе воздействие циклофосфамида на костный мозг овец}

Мясным мериносовым овцам вводился интравенозно циклофосфамид дозой 25 мг кг-1 в $2 \%$ концентрации. Проводились наблюдения за цитологической картиной костного мозга перед вводом и 22 дня после использования.

После подачи цитостатических препаратов отмечалась кратковременная и переходящая депрессия гемонэза, при этом больше пострадал красный компонент костного мозга. У белого компонента имела место депрессия лишь у более созревших клеток (нейтрофильные метамиелоциты и палочковидные гранулоциты). У обоих компонентов костного мозга после кратковременной депрессии продолжительностью 2-4 дня повысились не только эритропоэз, но и миелопоэз, длившиеся в течение всего периода анемии или лейкопении в периферийной крови. Было установлено, что подача циклофосфамида в приведенной дозе не вызывает никаких последствий в костном мозгу, который сохраняет способность к полной регенерации. Подтверждением данного вывода является также приспособление периферийной картины и весь ход эксперимента, когда не имели места нарушения клинического состояния овец. 


\section{References}

DRÁBEK, J. - HOFÍREK, B.: Cytostatic effect of cyclophosphamide on blood picture in sheep. Acta vet. Brno, 46, 1977: 293-300.

DOLNICK, D. J. - LINDHAL, I. L. - TERRIL, C. E. - REYNOLDS, P. J.: Cyclophosphamide as chemical ,,defleecing" agent for sheep. Nature, - 221, 1969: 467-470.

FERNBACH, D. J.: Symposium on cyclophosphamide in pediatric neoplasia Cancer Chemother. Rep., 51, 1967: 315-412.

SKALKA, J. - CHYLA, M. - VRZGULA, L.: Vpliv chemickéh ostrihania vlny u oviec pomocou cyklofosfamidu na zdravotný stav a niektoré hematologické a biochemické ukazatele. Živočišná výroba (Praha), 17, 1972: 45-52.

ZIEGLER, M. - SCHIMKE, E. - OETTEL, M. - CHEMNITIUS, K. H.: Zur chemischen Entvliesung beim Schaf mit Zytostatika. Arch. exp. Vet. Med., 26, 1972: 1031-1039. 